\title{
Kinetics of transit and degradation of the fiber from guinea grass silages enriched with waste from soybean pre-cleaning
}

\section{Filipe Ton Fialho ${ }^{1}$, Severino Delmar Junqueira Villela', Fernando de Paula Leonel ${ }^{2}$, Wagner Pessanha Tamy33, Raphael Pavesi Araujo4, Henrique Valentim Nunes Machado ${ }^{2}$}

\footnotetext{
${ }^{1}$ Universidade Federal dos Vales do Jequitinhonha e Mucuri, Departamento de Zootecnia, Diamantina, MG, Brasil.

${ }^{2}$ Universidade Federal de São João del Rei, Departamento de Zootecnia, São João del Rei, MG, Brasil.

${ }^{3}$ Universidade Estadual do Norte Fluminense Darcy Ribeiro, Campos dos Goytacazes, RJ, Brasil.

${ }^{4}$ Instituto Federal do Tocantins, Colinas do Tocantins, TO, Brasil
}

\begin{abstract}
The objective was to study the kinetics of transit and degradation of the fiber from guinea grass and the waste from soybean pre-cleaning (WSPC), ensiled with different proportions of mass $(0,100,150$, and $200 \mathrm{~g}$ WSPC/kg total mass). Four crossbred (Gyr $\times$ Holstein), fistulated cattle with an average body mass of $400 \pm 50 \mathrm{~kg}$ were organized in a $4 \times 4$ Latin square experimental design. The fiber utilized in the study of the transit kinetics was stained with chromium mordant, whereas the in situ technique was adopted for the degradation kinetics. The level of inclusion of WSPC only affected the true digestibility and the mean retention time. The addition of waste from soybean pre-cleaning to the silage of guinea grass is beneficial, in terms of kinetics of digestion and passage, at up to levels close to $100 \mathrm{~g} / \mathrm{kg}$, because after this quantity the fiber digestion and passage in and through the reticulo-rumen are impaired and there may be alterations in the ruminal environment that will affect the use of silage by animals.
\end{abstract}

Key Words: by-product, mathematical models, mean retention time, true digestibility

\section{Introduction}

The need to reduce costs and the impact on the production of animal-derived products leads to a greater focus on the rational use of all feed resources available. Thus, methods have been sought for the proper use of agroindustrial waste or by-products in animal feeding. The knowledge of the right use of these residues can certainly contribute to reducing the costs with animal feeding and the environmental impact (Carvalho Junior et al., 2010).

Several products originated from the industrialization or harvest, such as peelings and bagasse, have been produced on a large scale in Brazil. Yet, the largest part of this material has been underused in animal feeding due to its low nutrient concentration. Thus, research investigating the possibility of using these products, especially regarding their nutritional quality, has shown to be increasingly promising.

The investigation of the possibility and forms of utilization of a waste or any ingredient as feed for ruminant animals necessarily involves a study of its chemical composition. However, this chemical evaluation alone is not sufficient to decide on which is the best way to optimize

Received October 16, 2014 and accepted April 7, 2015.

Corresponding author: wagnertamy@yahoo.com.br

http://dx.doi.org/10.1590/S1806-92902015000600001

Copyright $@ 2015$ Sociedade Brasileira de Zootecnia. This is an Open Access article distributed under the terms of the Creative Commons Attribution Non-Commercial License, which permits unrestricted non-commercial use, distribution, and reproduction in any medium, provided the original work is properly cited. the input of nutrients from this feed or from the diet to a given animal category. The detailed study of the kinetics of degradation and transit of particles is an important tool to aid this decision making.

The kinetics of the fiber degradation, used as an evaluation trait for several feeds, when estimated using the technique of nylon bags incubated in rumen-fistulated cattle (Orskov et al., 1980), provides a fast and simple estimate of the degradation of nutrients and the evaluation of many feeds at the same time, having a low cost and rapidity as compared with the in vivo method. The in situ technique enables the contact of the evaluated feed with the ruminal environment, which makes it the best way to simulate this medium, although the feed is not subjected to all digestive events such as chewing, rumination, and the passage (Van Soest, 1994).

The passage rate of feed particles through the reticulorumen depends on properties of the feed itself as well as those of the animal in question. This passage kinetics has a direct influence on the degradation of the feed, increasing or decreasing it (AFRC, 1993). Therefore, the study of the kinetics of transit of particles of this feed through the gastrointestinal tract of ruminants provides useful tools to estimate the digestibility and also the input of nutrients to the animal.

Thus, the objective was to study the kinetics of transit and degradation of the fiber from guinea grass and the waste from soybean pre-cleaning, ensiled at different mass proportions. 


\section{Material and Methods}

For the experiment, the guinea grass (Panicum maximum cv. Mombaça), was harvested at 60 days of growth (regrowth), and at the moment of ensiling, the waste from soybean pre-cleaning (WSPC) was added at increasing levels to the total mass. The studied treatments were formed based on these levels of addition of WSPC. Silages with different proportions of guinea grass mass-toWSPC were formed, as follows: guinea grass silage without addition of WSPC (control); silage containing $900 \mathrm{~g} / \mathrm{kg}$ guinea grass $+100 \mathrm{~g} / \mathrm{kg} \mathrm{WSPC}$; silage containing $850 \mathrm{~g} / \mathrm{kg}$ guinea grass $+150 \mathrm{~g} / \mathrm{kg} \mathrm{WSPC}$; and silage containing $800 \mathrm{~g} / \mathrm{kg}$ guinea grass and $200 \mathrm{~g} / \mathrm{kg} \mathrm{WSPC}$.

The WSPC has great potential for ruminants (Table 1), and was obtained from the pre-cleaning of soybean in a grain processing and storage plant, and contains the coarsest fraction of the material harvested in the field (pods with unripe beans, pods with defective beans, leaves and pieces of soy-plant stems). This by-product is generated in soybean-producing regions at proportions of up to $1 \%$.

The ensiling process started with a mechanical cut (tractor-ensiling machine set) of the guinea grass, and the WSPC was subsequently added at the mass proportions described above, and the total material was inserted in mini-silos (PVC containers with capacity of $12 \mathrm{~kg}$ of fresh matter, at a storage density of $500 \mathrm{~kg} / \mathrm{m}^{3}$; Bunsen valves were adapted on the lids to enable gas flow). After filling, these containers were sealed hermetically with adhesive tapes to prevent air exchange with the environment.

After the period for stabilization of the material ( 30 days), the experimental silos were open to determine the chemical composition and to mark the fiber of the silages under study.

For the estimate of the fiber transit kinetics, approximately $3 \mathrm{~kg}$ of silage from each treatment were placed in a container to boil for one hour with a commercial neutral detergent at the rate of $100 \mathrm{~g}$ of dry sample for $100 \mathrm{~mL}$ of detergent per liter of water, as described by Udén et al. (1980). After this procedure, the material was filtered in a cotton-fabric bag and washed with running water from tap

Table 1 - Chemical values of waste from soybean pre-cleaning (WSPC) and guinea grass

\begin{tabular}{lcc}
\hline Variable & WSPC & Guinea grass \\
\hline Dry matter $(\mathrm{g} / \mathrm{kg})$ & 737.3 & 262.7 \\
Crude protein $(\mathrm{g} / \mathrm{kg})$ & 192.3 & 71.4 \\
Neutral detergent fiber $(\mathrm{g} / \mathrm{kg})$ & 513.7 & 737.1 \\
Acid detergent fiber $(\mathrm{g} / \mathrm{kg})$ & 313.3 & 377.7 \\
\hline
\end{tabular}

until the water was clear to remove the soluble contents, and then dried in an oven at $55 \pm 5^{\circ} \mathrm{C}$ for $72 \mathrm{~h}$.

Next, a potassium dichromate solution $\left(\mathrm{K}_{2} \mathrm{Cr}_{2} \mathrm{O}_{7} \cdot 2 \mathrm{H}_{2} \mathrm{O}\right)$ was made at the proportion of $13 \%$ chromium in relation to the weight of the fiber to be stained. This solution was diluted in water in a glass container with previous immersion of the fiber in this solution. The container was covered with foil and kept in an oven at $105^{\circ} \mathrm{C}$ for $24 \mathrm{~h}$. After this procedure the material was conditioned in a cotton-fabric bag and washed in running water to remove the excess potassium dichromate. Afterwards, the material was immersed in a commercial ascorbic acid solution at the proportion of half the weight of the fiber, and left to rest for one hour until reaching an intense green color. Soon after this, the material was once again conditioned in a cotton-fabric bag and washed several times until complete clearing of the water, and then dried in a forced-ventilation oven at $55 \pm 5^{\circ} \mathrm{C}$ for $72 \mathrm{~h}$, thus generating the chromium-mordant NDF.

Four Holstein $\times$ Gyr crossbred castrated cattle with an approximate weight of $400 \mathrm{~kg}$, cannulated in the rumen according to the technique described by Leão and Coelho da Silva (1980) and Leão et al. (1978), were distributed in a Latin square design with four treatments, four animals, and four experimental periods. The animals were kept in a confined regime, in individual pens, and fed a diet consisting of guinea grass supplied ad libitum plus $2 \mathrm{~kg}$ of a concentrate based on corn, soybean meal $(25 \% \mathrm{CP})$, and a mineral mix during the trial. The feed was supplied twice daily, at around $07.00 \mathrm{~h}$ and $15.00 \mathrm{~h}$.

Stained samples were placed directly in the rumen via ruminal cannulae at the amount of $200 \mathrm{~g}$ per animal. Feces were collected at times zero (immediately after administering the chromium-complexed fiber), 1, 2, 4, $6,8,12,16,20,24,28,32,36,40,44,48,56,64,72,80$, $88,96,120,132,144$, and $196 \mathrm{~h}$, to estimate the passagekinetic parameters of the particles. After these collections at the indicated times, the samples were dried in a forcedventilation oven at $55 \pm 5{ }^{\circ} \mathrm{C}$ for $72 \mathrm{~h}$ and then processed in a mill with 1-mm-mesh sieve. Approximately $200 \mathrm{mg}$ of feces respective to each incubation time, animal, and period were diluted in a nitric-perchloric acid solution to remove the organic matter and for subsequent reading of the chromium concentration by atomic absorption spectrometry, following the methodology described by Kimura \& Miller (1957).

The profiles of concentration of the marker in the feces were described by the generalized two-compartment model suggested by Matis et al. (1989). The parameters generated in this model provide estimates that explain the dynamics of the rate of passage or transit of fibrous particles through the gastrointestinal tract of ruminants in general. 
Concurrently with the study of transit kinetics, the ruminal degradability of the fiber from the silages was also analyzed. To this end, the in situ technique was used, which consists of incubating the materials under study for pre-set times in the rumen of the animals. Nylon bags $(13 \times 7 \mathrm{~cm}$; $50-\mu \mathrm{m}$ pore) containing approximately $1 \mathrm{~g}$ of sample each were used, maintaining a bag surface ratio of $25 \mathrm{mg} \mathrm{DM} / \mathrm{cm}^{2}$, in accordance with recommendations of Kirkpatrick and Kennelly (1987).

The incubation times adopted were $0,6,18,48$, and $96 \mathrm{~h}$, according to Sampaio (1994), such that at each time all treatments were incubated in each animal. The bags were tied in sequential order on the links of a chain, which contained a weight on its extremity. This weight worked as an anchor, causing the bags to be immersed in the ruminal content, which promoted an effective activity of the ruminal microorganisms on the samples.

Bags were incubated in the rumen in a reversed chronological order (infused at the times set and (all) removed at the end of the countdown).

After they were removed, bags were washed in running water until complete clearing and then conditioned in a forced-ventilation oven at $55 \pm 5{ }^{\circ} \mathrm{C}$ for $72 \mathrm{~h}$. The bags corresponding to time zero were not incubated in the rumen but underwent the same cleaning process, simultaneously with the others.

After the drying process, the bags were open and their contents were analyzed for the levels of dry matter (DM; method 967.03, AOAC, 1998) and neutral detergent fiber (NDF; method 2002.04, Mertens, 2002)

The model utilized to estimate the parameters of degradation kinetics of the fiber consists of a simple firstorder equation, which was proposed by Smith et al. (1971). A parameter representing the discrete lag time was added to this model; this inclusion was suggested by Mertens and Loften (1980) and reaffirmed by Vieira et al. (2008a), who justified its use by the substantial improvement of its predictive ability.

Variables $A$ and $U$, both expressed in $\mathrm{g} \mathrm{kg}^{-1}$, derived from the degradation kinetics study, were normalized as proposed by Waldo et al. (1972) so that they could demonstrate a suitable proportion between each other, becoming $A n$ and $U n$. The variables tested in the degradability study were: potentially digestible fraction of the normalized fiber $(A n)$, indigestible fraction of the normalized fiber $(U n)$, discrete lag $(L)$, digestion rate $(c)$, mean retention time in the rumenreticulum $(M R T)$, true digestibility $(T D)$ and fiber rumenfill effect $(R F)$. Variable $L$, expressed in hours, represents the time for preparation and colonization of the substrate in the rumen until the effective start of digestion. Variable $c$, in turn, quantifies the proportion of fiber digested in the rumen per time unit, and is expressed in $\mathrm{h}^{-1}$.

The turnover, or mean retention time in the reticulorumen $(M R T)$, was estimated based on biological interpretations, in which both ascending and descending phases of the profile of excretion of the markers in the feces exerted an influence on the retention of the particles in the reticulo-rumen (Vieira et al., 2008b). This parameter in the model is expressed in hours, and was estimated according to the equation of Matis et al. (1989).

The fiber true digestibility coefficient $(T D)$ is dimensionless and was estimated using the model deduced by Vieira et al. (2008b), as well as the rumen fill $(R F)$, expressed in days, which was obtained by using the model to estimate the ruminal content, from the same author, but the multiplication by the fiber intake was discarded, as can be seen below:

$R F=A\left\{v \sum_{i=1}^{N}\left[\lambda^{i-1} /(\lambda+c)^{i}\right]+\lambda^{N} /\left[(\lambda+c)^{N}(k+c)\right]\right\}+U[N / \lambda+1 / k]$

The parameters of the adjusted model for the kinetics of passage and degradability profiles were estimated through the NLIN procedure of SAS (Statistical Analysis System, version 9.0) software. Both the Newton and Marquardt algorithms were used. Initially, the preferred form or algorithm was that of Newton, due to its good performance in terms of convergence; however, whenever the correlations among the estimates of the parameters were high, we opted for Marquardt's algorithm.

The choice of the best version for the time-dependency order $(N)$ and consequently of the best model to explain the passage rate was evaluated by the calculation of Akaike's information criterion $\left(A I C c_{h}\right)$ (Akaike, 1974; Burnham and Anderson, 2004). The $A I C c_{b}$ was calculated as the sum of the squares of the error $\left(S S E_{h}\right)$, number of estimated parameters including the residual variance $\left(\Theta_{h}\right)$, and the size of the sample $\left(n_{h}\right)$ for all the different versions of $N, \forall h=1,2, \ldots, 6$. The differences between the $A I C c_{h}\left(\Delta_{h}\right)$ values, the probability of likelihood $\left(w_{h}\right)$, and the evidence ratio $\left(E R_{h}\right)$ were obtained according to the models proposed by Vieira et al. (2012).

The estimates of the parameters of the profiles of passage rate were adjusted according to robust-regression procedures (Beaton and Tukey, 1974), to reduce the effect of discrepant observations (outliers) and eliminate subjectivity during the appreciation of these points.

The adopted statistical model was as follows:

$$
Y_{i j}=\mu+\alpha_{i}+\beta_{j}+e_{i j}
$$

in which the fixed effect is represented by the effect of the mean $(\mu)$ and by the effect of treatment $\left(\alpha_{i}\right)$, whereas the 
random effect is attributed to the effect of the animal $\left(\beta_{j}\right)$ and to the effect of the random error $\left(e_{i j}\right)$.

Homogeneous and heterogeneous variance and covariance matrix structures were tested (Vieira et al., 2012), and then Akaike's criterion was used to choose the best structure. The equations proposed by Neter and Wasserman (1974) were utilized to calculate the points of maximum for $\mathrm{x}$ and $\mathrm{y}$ on variable $T D$ and their confidence intervals.

\section{Results}

Changes in the chemical variables of the silages according to the level of enrichment of guinea grass with WSPC occurred (Table 2), but were not the focus of this study.

Table 2 - Concentrations of protein (CP) and fiber (NDF) in the dry matter of the silage, as a function of the enrichment with the waste from soybean pre-cleaning (WSPC)

\begin{tabular}{lccccc}
\hline & \multicolumn{5}{c}{ Level of WSPC $\left(\mathrm{g} \mathrm{kg}^{-1}\right)$} \\
\cline { 2 - 6 } Variable & 0 & 50 & 100 & 150 & 200 \\
\hline CP $\left(\mathrm{g} \mathrm{kg}^{-1}\right)$ & $6.3 \mathrm{~d}$ & $7.8 \mathrm{c}$ & $9.3 \mathrm{~b}$ & $12.2 \mathrm{a}$ & $12.9 \mathrm{a}$ \\
$\mathrm{NDF}\left(\mathrm{g} \mathrm{kg}^{-1}\right)$ & $74.9 \mathrm{a}$ & $69.62 \mathrm{~b}$ & $68.33 \mathrm{~b}$ & $63.83 \mathrm{c}$ & $63.45 \mathrm{c}$ \\
\hline
\end{tabular}

Means followed by different letters in the same row differ statistically from each other.

$\mathrm{CP}$ - crude protein; NDF - neutral detergent fiber.
In this study, a more adequate adjustment in relation to the variance and covariance structures (Table 3) was observed in all variables when the homogenous variance and covariance structure was used, which is justified by the lower values found for $A I C c_{h}, \Delta_{h}$, and $E R_{h}$, and consequently the higher values observed for the probability of likelihood $\left(w_{h}\right)$.

An effect of treatment (inclusion of WSPC) was found only on $T D$ and $M R T$; the P-values obtained for these variables were 0.0524 and 0.0513 , respectively.

The other parameters of the models (potentially digestible fraction, indigestible fraction, digestion rate, lag, and rumen fill) did not show to be significantly affected (Table 4).

The estimated behavior of the true-digestibility model showed a quadratic response (Figure 1), with $\mathrm{P}=0.0374$. The maximum point for the values of $\mathrm{x}$ in variable $T D$ was $100.3 \mathrm{~g} \mathrm{~kg}^{-1}$, with a confidence interval between 92.2 and $108.4 \mathrm{~g} \mathrm{~kg}^{-1}$. The maximum point for $\mathrm{Y}$, however, was 3.2 , with a confidence interval between 2.6 and 3.7.

Unlike the trend observed for TD, MRT increased linearly, with $\mathrm{P}=0.0499$; according to the model estimate, there was an increase of $0.0514 \mathrm{~h}$ per unit of increment with the inclusion of WSPC (Figure 2).

Table 3 - Criterion of choice of the best adjustment of variance and covariance structure (VC), considering corrected Akaike's criterion $\left(A I C c_{h}\right), \Delta_{h}$, probability of likelihood $\left(w_{h}\right)$ and evidence ratio $\left(E R_{h}\right)$

\begin{tabular}{|c|c|c|c|c|c|}
\hline Parameter & $\mathrm{VC}$ & $A I C c_{h}$ & $\Delta_{h}$ & $w_{h}$ & $E R_{h}$ \\
\hline$A n$ & $\begin{array}{l}\text { Homogeneous } \\
\text { Heterogeneous }\end{array}$ & $\begin{array}{c}-2.6 \\
5.6\end{array}$ & $\begin{array}{c}0 \\
8.2\end{array}$ & $\begin{array}{l}0.984 \\
0.016\end{array}$ & $\begin{array}{c}1 \\
60.3\end{array}$ \\
\hline$U n$ & $\begin{array}{l}\text { Homogeneous } \\
\text { Heterogeneous }\end{array}$ & $\begin{array}{c}-2.6 \\
5.6\end{array}$ & $\begin{array}{c}0 \\
8.2\end{array}$ & $\begin{array}{l}0.984 \\
0.016\end{array}$ & $\begin{array}{c}1 \\
60.3\end{array}$ \\
\hline$c$ & $\begin{array}{l}\text { Homogeneous } \\
\text { Heterogeneous }\end{array}$ & $\begin{array}{l}-57.3 \\
-54.2\end{array}$ & $\begin{array}{c}0 \\
3.1\end{array}$ & $\begin{array}{l}0.825 \\
0.175\end{array}$ & $\begin{array}{c}1 \\
4.7\end{array}$ \\
\hline$L$ & $\begin{array}{l}\text { Homogeneous } \\
\text { Heterogeneous }\end{array}$ & $\begin{array}{c}91.4 \\
102\end{array}$ & $\begin{array}{c}0 \\
10.6\end{array}$ & $\begin{array}{l}0.995 \\
0.005\end{array}$ & $\begin{array}{c}1 \\
200.3\end{array}$ \\
\hline$R F$ & $\begin{array}{l}\text { Homogeneous } \\
\text { Heterogeneous }\end{array}$ & $\begin{array}{c}11.3 \\
21\end{array}$ & $\begin{array}{c}0 \\
9.7\end{array}$ & $\begin{array}{l}0.992 \\
0.008\end{array}$ & $\begin{array}{c}1 \\
127.7\end{array}$ \\
\hline$T D$ & $\begin{array}{l}\text { Homogeneous } \\
\text { Heterogeneous }\end{array}$ & $\begin{array}{l}-27.5 \\
-23.3\end{array}$ & $\begin{array}{c}0 \\
4.2\end{array}$ & $\begin{array}{l}0.891 \\
0.109\end{array}$ & $\begin{array}{c}1 \\
8.2\end{array}$ \\
\hline$M R T$ & $\begin{array}{l}\text { Homogeneous } \\
\text { Heterogeneous }\end{array}$ & $\begin{array}{l}88.7 \\
96.6\end{array}$ & $\begin{array}{c}0 \\
7.9\end{array}$ & $\begin{array}{l}0.981 \\
0.019\end{array}$ & $\begin{array}{c}1 \\
51.9\end{array}$ \\
\hline
\end{tabular}

$A n$ - potentially digestible fraction $\left(\mathrm{g} \mathrm{kg}^{-1}\right) ; U n$ - indigestible fraction $\left(\mathrm{g} \mathrm{kg}^{-1}\right) ; c$ - digestion rate $\left(\mathrm{h}^{-1}\right) ; L$ - lag $(\mathrm{h}) ; R F$ - rumen fill (d); TD - true digestibility $(\mathrm{dmls}) ; M R T$ - mean retention time (h).

Table 4 - Inclusion levels of the waste from soybean pre-cleaning and their respective confidence intervals for the different parameters

\begin{tabular}{lcccc}
\hline & \multicolumn{4}{c}{ Inclusion level $\left(\mathrm{g} \mathrm{kg}^{-1}\right)(95 \%$ confidence interval $)$} \\
\cline { 2 - 5 } Parameter & 0 & 100 & 150 & 200 \\
\hline$A n\left(\mathrm{~g} \mathrm{~kg}^{-1}\right)$ & $0.417(0.247 ; 0.587)$ & $0.494(0.324 ; 0.664)$ & $0.600(0.430 ; 0.770)$ & $0.368(0.198 ; 0.538)$ \\
$U n\left(\mathrm{~g} \mathrm{~kg}^{-1}\right)$ & $0.583(0.413 ; 0.753)$ & $0.506(0.336 ; 0.676)$ & $0.400(0.230 ; 0.570)$ & $0.632(0.462 ; 0.802)$ \\
$c\left(\mathrm{~h}^{-1}\right)$ & $0.023(0.005 ; 0.040)$ & $0.039(0.022 ; 0.057)$ & $0.012(-0.005 ; 0.030)$ & $0.030(0.013 ; 0.048)$ \\
$L(\mathrm{~h})$ & $17.139(8.591 ; 25.688)$ & $11.186(2.638 ; 19.735)$ & $8.490(-0.059 ; 17.038)$ & $10.631(2.083 ; 19.180)$ \\
$R F(\mathrm{~d})$ & $1.673(1.370 ; 1.9769)$ & $1.937(1.634 ; 2.241)$ & $1.942(1.639 ; 2.246)$ & $2.020(1.716 ; 2.323)$ \\
\hline
\end{tabular}

$A n$ - potentially digestible fraction; $U n$ - indigestible fraction; $c$ - digestion rate; $L$ - lag; $R F$ - rumen fill. 


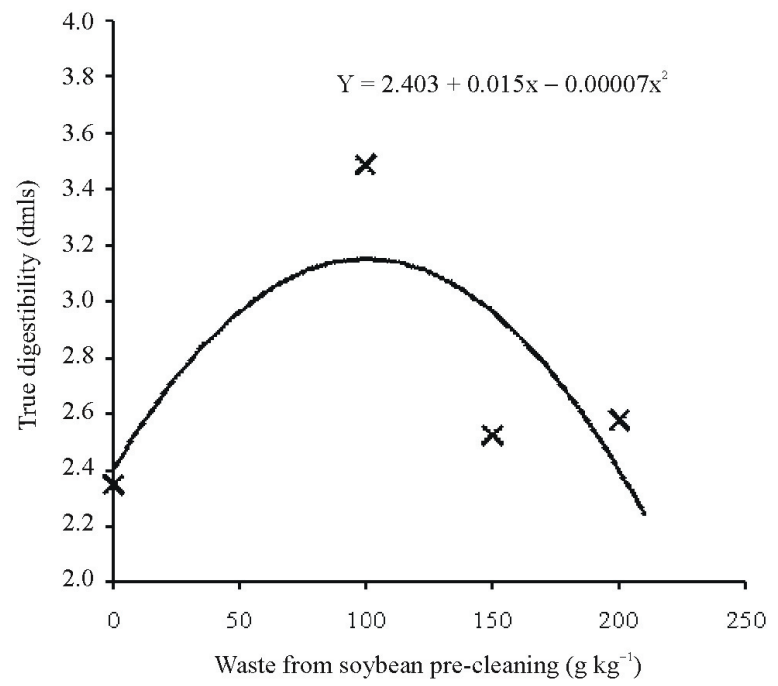

Figure 1 - Quadratic regression model adjusted for the true digestibility according to the applied treatments and its estimated equation.

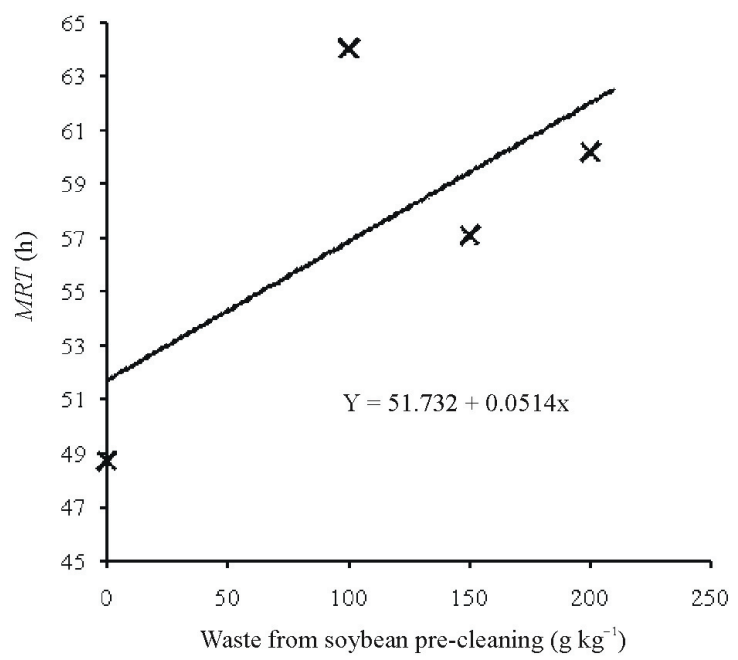

Figure 2 - Model of increasing linear regression adjusted for the mean retention time (MRT) according to the applied treatments and its estimated equation.

\section{Discussion}

The calculation of Akaike's criterion (Akaike, 1974) allows us to compare different hypotheses, and based on the obtained results, select the one that best predicts reality according to the evaluated dataset. Although the homogeneous variance and covariance structure has a lower number of parameters, it may, in some cases, result in in worse adjustment, with higher values on both Akaike's corrected criterion and delta and evidence ratio, and lower estimates for the probability of likelihood. However, this behavior was not observed in the present study.
Mathematical models applied to animal nutrition have been used to quantify the nutritional value of diets and estimate the animal performance. These models are based on the evaluated substrate and on the ruminal digestion kinetics to estimate the availability of nutrients (carbohydrates and proteins) for the microbial growth (Abreu et al., 2014). The optimization of diets for ruminants has been widely investigated, especially concerning their ability to ingest and consume fiber (Vieira et al., 2008a; Jardim et al., 2013).

Theoretically, it is expected that with the increase in the $M R T$ values, the TD estimate will also increase, given that the longer a feed remains in the rumen, the more it will undergo the effects of fermentation and degradation. However, in the present study it was found that the digestibility of the fiber from the silage had a quadratic response, whereas the time of retention of the fibrous particles inside the reticulo-rumen responded linearly. This type of behavior is not uncommon, and has already been reported in the literature (Vieira et al., 1997). The occurrence of this phenomenon may be related to the characterization of the ruminal microorganisms, which may vary according to the type of feeding (Van Soest, 1994). With the marked increase in the source of rapidly fermentable feed, the pattern of ruminal microorganisms might have been modified, which means that very high levels of inclusion of the WSPC in the silage might have affected negatively the amount of fiber-degrading bacteria, and this fact might have resulted in the decrease in $T D$ of the fiber from the silages. Still, mathematically speaking, the nature of the equations utilized for the estimate of the parameters of $T D$ and $M R T$ differs. The digestion and time of retention of the particles in the rumen result from the degradation and passage; in the model used to calculate $T D$ these rates are on the numerator and denominator, and compete against each other, which may lead to the observed quadratic effect. In the model used to estimate the MRT, however, the rates of degradation and escape are only on the denominator, and instead of competing they aggregate, generating an increasing linear effect.

In the animals fed forages, the flow of saliva and the rumination are stimulated, and the rate of dilution of the fluids is high (Russell, 2002). This fact indicates that the ruminal escape is facilitated by the salivation and dilution provided by forage feeds, and when roughage feeds are proportionally substituted for concentrate sources, which are more rapidly degraded in the rumen, the salivation and rate of dilution of the ruminal fluid decrease by around $15 \%$ (Russell, 2002), which may cause an elongation in the time of residence of this material inside the organ and a consequent increase in $M R T$. 


\section{Conclusions}

Addition of the waste from soybean pre-cleaning to guinea grass silages benefits the kinetics of digestion and passage through the gastrointestinal tract of cattle, considering the inclusion levels of soybean hulls between 92 and $108 \mathrm{~kg} / 1,000 \mathrm{~kg}$ of ensiled material. From this limit, the digestion and passage of the fiber in and through the reticulo-rumen are impaired, i.e., the clearance of the fiber by the reticulo-rumen is delayed, which may result in lower use of the silage by the animals.

\section{References}

Abreu, M. L. C.; Vieira, R. A. M.; Rocha, N. S.; Araujo, R. P.; Gloria, L. S.; Fernandes, A. M.; Lacerda, P. D. and Gesualdi Jr., A. G. 2014. Clitoria ternatea L. as a potential high quality forage legume. Asian-Australasian Journal of Animal Science 27:2.

AFRC - Agricultural and Food Reaserch Council. 1993. Energy and protein requirements of ruminants. CAB International, Wallingford.

Akaike, H. 1974. A new look at the statistical model identification. IEEE Transactions on Automatic Control 19:716-723.

AOAC - Association of Official Agricultural Chemists. 1998. Official methods of analysis. 16th ed., 4th rev. AOAC International, Gaithersburg.

Beaton, A. E. and Tukey, J. W. 1974. The fitting of power series, meaning polynomials, illustrated on bandspectroscopic data. Technometrics 16:147-185.

Burnham, K. P. and Anderson, D. R. 2004. Multimodel inference: Understanding AIC and BIC in model selection. Sociological Methods \& Research 33:261-304.

Carvalho Junior, J. N.; Pires, A. J. V.; Veloso, C. M.; Silva, F. F.; Reis, R. A. and Carvalho, G. G. P. 2010. Digestibilidade aparente da dieta com capim-elefante ensilado com diferentes aditivos. Arquivos Brasileiros Medicina Veterinária e Zootecnia 62:889-897.

Jardim, J. G.; Vieira, R. A. M.; Fernandes, A. M.; Araujo, R. P.; Gloria, L. S.; Rohem Jr., N. M.; Rocha, N. S. and Abreu, M. L. C. 2013. Application of a nonlinear optimization tool to balance diets with constant metabolizability. Livestock Science 158:106-117.

Kimura, F. T. and Miller, V. L. 1957. Improved determination of chromic oxide in cal feed and feces. Journal Agriculture Foodstuffs Chemistry 5:216.

Kirkpatrick, B. K. and Kennelly, J. J. 1987. In situ degradability of protein and dry matter from single protein sources and from a total diet. Journal of Animal Science 65:567-576.

Leão, M. I. and Coelho da Silva, J. F. 1980. Técnicas de fistulação de abomaso em bezerros. p.37. In: Anais do 1 Congresso Brasileiro de Zootecnia; 17a Reunião Anual da Sociedade Brasileira de Zootecnia. Sociedade Brasileira de Zootecnia, Fortaleza.
Leão, M. I.; Coelho da Silva, J. F. and Carneiro, L. D. H. M. 1978. Implantação de fístula ruminal e cânula duodenal reentrante em carneiros, para estudos de digestão. Revista Ceres 25:42-54.

Matis, J. H.; Wehrly, T. E. and Ellis, W. C. 1989. Some generalized stochastic compartment models for digesta flow. Biometrics 45:703-720.

Mertens, D. R. 2002. Gravimetric determination of amylase-treated neutral detergent fiber in feeds with refluxing in beakers or crucibles: collaborative study. Journal of AOAC 85:1217-1240.

Mertens, D. R. and Loften, J. R. 1980. The effect of starch on forage fiber digestion kinetics in vitro. Journal of Dairy Science 63:1437-1446.

Neter, J. and Wasserman, W. 1974. Applied linear statistical models. Richard D. Irwin, Inc., Homewood.

Orskov, E. R.; Hovell, F. D. B. and Mould, F. 1980. The use of the nylon bag technique for the evaluation of feedstuffs. Tropical Animal Production 5:195-213.

Russell, J. B. 2002. Rumen microbiology and its role in ruminant nutrition. Russell J.B., Ithaca, NY.

Sampaio, I. B. M. 1994. Contribuições estatísticas e de técnica experimental para ensaios de degradabilidade de forragens quando avaliada in situ. p.81-88. In: Anais da 31a Reunião Anual da Sociedade Brasileira de Zootecnia; Simpósio Internacional de Produção de Ruminantes. Sociedade Brasileira de Zootecnia, Maringá.

Smith, L. W.; Goering, H. K.; Waldo, D. R. and Gordon, D. H. 1971. In vitro digestion rate of forage cell wail components. Journal of Dairy Science 54:71-76.

Udén, P.; Colucci, P. E. and Van Soest, P. J. 1980. Investigation of chromium, cerium and cobalt as markers in digesta. Rate of passage studies. Journal of the Science of Food and Agriculture 31:625-632.

Van Soest, P. J. 1994. In: Nutritional ecology of the ruminant. Cornell University Press, Ithaca.

Vieira, R. A. M.; Campos, P. R. S. S.; Silva, J. F. C.; Tedeschi, L. O. and Tamy, W. P. 2012. Heterogeneity of the digestible in soluble fiber of selected forages in situ. Animal Feed Science and Technology 171:154-166.

Vieira R. A. M.; Pereira J. C.; Malafaia P. A. M. and Queiroz A. C. 1997. The influence of elephant-grass (Pennisetum purpureum Schum., Mineiro variety) growth on the nutrient kinetics in the rumen. Animal Feed Science and Technology 67:151-161.

Vieira, R. A. M.; Tedeschi, L. O. and Cannas, A. 2008a. A generalized compartmental model to estimate the fibre mass in the ruminoreticulum: 1. Estimating parameters of digestion. Journal Theoretical Biology 255:345-356

Vieira, R. A. M.; Tedeschi, L. O. and Cannas, A. 2008b. A generalized compartmental model to estimate the fibre mass in the ruminoreticulum: 2 . Integrating digestion and passage. Journal of Theoretical Biology 255:357-368.

Waldo, D. R.; Smith, L.W. and Cox, E. L. 1972. Model of cellulose disappearance from the rumen. Journal of Dairy Science $55: 125-129$ 


\section{ERRATUM}

The article "Kinetics of transit and degradation of the fiber from guinea grass silages enriched with waste from soybean pre-cleaning", was published in Revista Brasileira de Zootecnia, 44(6):201-206, 2015, without the Acknowledgments section included.

Where it should read:

\section{Acknowledgments}

To Fundação de Amparo à Pesquisa do Estado de Minas Gerais (FAPEMIG) for the financial support of this project. 